\title{
PERFORMANSI ALGORITMA NAIVE BAYES DAN NEURAL NET UNTUK PREDIKSI KECOCOKAN PASIEN DENGAN PENGOBATAN IMMUNOTERAPI DAN CRYOTHERAPY
}

\section{PERFORMANCE OF NAIVE BAYES ALGORITHM AND NEURAL NET FOR PREDICTING THE MATCH OF PATIENTS WITH IMMUNOTHERAPY AND CRYOTHERAPY TREATMENT}

\author{
Herliyani Hasanah $^{1^{*}}$, Nurmalitasari ${ }^{2}$, Ahmad Tomi ${ }^{3}$ \\ ${ }^{1,2,3}$ Fakultas Ilmu Komputer, Universitas Duta Bangsa Surakarta \\ *E-mail: herliyani_hasanah@udb.ac.id
}

\begin{abstract}
ABSTRAK
Human papillomavirus (HPV) merupakan bagian dari papillomavirus. Infeksi HPV dapat muncul pada kutil kulit dengan berbagai ukuran dan bentuk. Penyakit kutil bisa menjadi kondisi yang parah dan mungkin berhubungan dengan perdarahan lokal. Penyakit kutil umumnya diobati dengan cryotherapy dan immunotherapy. Cryotherapy dan immunotherapy tidak selalu berhasil dan tidak ada pedoman dermatologis resmi yang ada dan dapat digunakan untuk menentukan keberhasilan metode ini pada pasien. Walaupun cryotherapy dan immunotherapy sudah cukup mukhtahir namun masih diperlukan penelitian untuk mengetahui tingkat keberhasilan dengan kondisi dan parameter yang ada.. Penelitian ini bertujuan untuk meneliti efektifitas Algoritma Naive Bayes dan Neural Net untuk memprediksi apakah pasien cocok dengan metode pengobatan immunoterapi dan cryotherapy. Hasil penelitian ini efektifitas menggunakan neural network yang menghasilkan accuracy cukup tinggi $91.3 \%$ untuk data cryotherapy dan $82.61 \%$ untuk data immunotherapy.
\end{abstract}

Kata kunci: cryotherapy, immunotherapy, Naive Bayes, Neural Net

\begin{abstract}
Human papillomavirus (HPV) is part of the papillomavirus. HPV infection can appear on skin warts of various sizes and shapes. Warts can be a severe condition and may be associated with local bleeding. Warts are generally treated with cryotherapy and immunotherapy. Cryotherapy and immunotherapy are not always successful and no official dermatological guidelines exist that can be used to determine the success of these methods in patients. Although cryotherapy and immunotherapy are quite sophisticated, research is still needed to determine the success rate with existing conditions and parameters. This study aims to examine the effectiveness of the Naive Bayes Algorithm and Neural Net to predict whether a patient is suitable for the treatment method of immunotherapy and cryotherapy. The results of this study are the effectiveness of using a neural network which produces a fairly high accuracy of $91.3 \%$ for cryotherapy data and $82.61 \%$ for immunotherapy data.
\end{abstract}

Keywords: cryotherapy, immunotherapy, Naive Bayes, Neural Net

\section{PENDAHULUAN}

Human papillomavirus (HPV) merupakan bagian dari papillomavirus [1]. Infeksi HPV dapat muncul pada kutil kulit dengan berbagai ukuran dan bentuk [2]. Penyakit kutil dicirikan dengan berdaging, kasar, pertumbuhan kasar yang paling sering muncul di tangan, jari atau di telapak kaki. Jenis lain dari kutil juga dapat muncul di bagian lain dari tubuh seperti wajah, lengan atau kaki dan terkadang tumbuh di alat kelamin atau daerah anus. Dua jenis kutil yang paling umum adalah 
kutil biasa (verrucae vulgaris) yang biasanya muncul di tangan, dan kutil plantar (verrucae plantaris) yang banyak muncul di telapak kaki [3-5]. Penyakit kutil bisa menjadi kondisi yang parah dan mungkin berhubungan dengan perdarahan lokal. Penyakit kutil umumnya diobati dengan cryotherapy, namun pengobatan tersebut memiliki banyak efek samping, menyakitkan, dan banyak tahapan perawatannya. Immunotherapy menjadi alternatif pengobatan yang lain, berdasarkan pada aktivasi kekebalan sistem tubuh untuk berurusan dengan virus [6].

Cryotherapy dan immunotherapy tidak selalu berhasil dan tidak ada pedoman dermatologis resmi yang ada dan dapat digunakan untuk menentukan keberhasilan metode ini pada pasien [7-8]. Namun, penelitian menggunakan machine learning menjadi terobosan ntuk menentukan aturan yang dapat membantu dokter menentukan apakah pengobatan dengan salah satu dari dua terapi akan menghasilkan hasil yang menguntungkan. Saat ini metode machine learning sudah banyak diterapkan dalam aplikasi medis seperti pengetahuan perkembangan penyakit, mendiagnosis serta memilih metode pengobatan.

Berikut adalah beberapa penelitian yang dijadikan kajian literature dalam penelitian ini. Penelitian Yashik Singh, akurasi rata-rata prediksi immunotherapy adalah 88,6\% $\pm 8,0 \%$ sedangkan ukuran yang sama untuk prediksi cryotherapy adalah 94,6\% $\pm 4,0 \%$. Model immunotherapy dan cryotherapy yang paling efisien memiliki akurasi $100 \%$, yang menunjukkan hasil pengobatan yang benar bila diterapkan pada semua kasus uji [9]. Menurut Anuradha dan Velmurugan [10], menyatakan hasil klasifikasi seperti klasifikasi Naive Bayes dan Bayes Net memiliki performa yang sangat baik dibandingkan pengklasifikasian yang lain dengan akurasi keseluruhan tertinggi dengan nilai akurasi lebih tinggi dari $70 \%$. Penelitian tentang komparasi algoritma klasifikasi yaitu Decision Tree, Nä̈ve Bayes, $k$-Nearest Neighbour, Random Forest, dan Decison Stump untuk penyakit jantung. Hasil penelitian menunjukkan Bahwa algoritma random forest dan decision stump melakukan performa terbaik dalam Pengklasifikasi di dataset, C4.5 dan Naïve bayes juga tampil baik, kemudian k-NN Merupakan algoritma yang kurang baik diimplementasikan dalam dataset [11].

\section{METODOLOGI}

Berikut ini kerangka penelitian pada komparasi Algoritma Naive Bayes dan Neural Net untuk Immunoterapi dan Cryotherapy pada penyakit kutil :

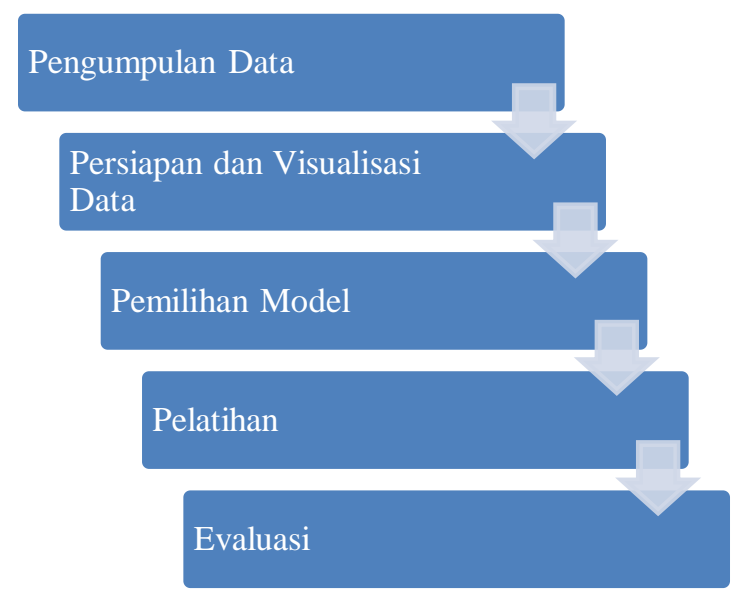

Gambar 1. Tahapan Metodologi Penelitian

a. Pengumpulan Data

Data yang digunakan dalam penelitian ini data sekunder immunotherapy dan cryotherapy yang diperoleh dari Repository UCI (Univercity California Invene). Dataset terdiri dari 90 data itu dikaitkan dengan pasien yang menjalani cryotherapy dan 90 data berkaitan dengan pasien yang menjalani immunoterapi. Data cryotherapy terdiri dari sex, age, time, number of warts, type, area dan class. Data immunotherapy terdiri dari sex, age, time, number of warts, type, area, diameter dan result of treatment. Tabel 1 menjelaskan input dari algoritma pembelajaran mesin secara lebih rinci. Outputnya adalah klasifikasi biner juga menunjukkan sukses atau kegagalan terapi.

Tabel 1. Atribut Dataset

\begin{tabular}{|c|c|c|c|}
\hline \multirow{3}{*}{\begin{tabular}{l}
\multicolumn{1}{c}{ Dataset } \\
Cryothera \\
py/ \\
immunoth \\
erapy
\end{tabular}} & \multicolumn{2}{|c|}{ Atribut } & \multirow{2}{*}{$\begin{array}{l}\text { Value } \\
\text { Male }\end{array}$} \\
\hline & Sex & $\begin{array}{l}\text { Jenis } \\
\text { kelamin } \\
\text { pasien }\end{array}$ & \\
\hline & & & Female \\
\hline & Age (yr) & $\begin{array}{l}\text { Usia } \\
\text { Pasien }\end{array}$ & $15-67$ \\
\hline & $\begin{array}{l}\text { Time } \\
\text { (mo) }\end{array}$ & $\begin{array}{l}\text { Waktu } \\
\text { berlalu } \\
\text { sebelum } \\
\text { perawatan }\end{array}$ & $0-12$ \\
\hline & Number & $\begin{array}{l}\text { Angka } \\
\text { kutil }\end{array}$ & $1-19$ \\
\hline & Type & Jenis kutil & $\begin{array}{l}\text { Commo } \\
n\end{array}$ \\
\hline
\end{tabular}




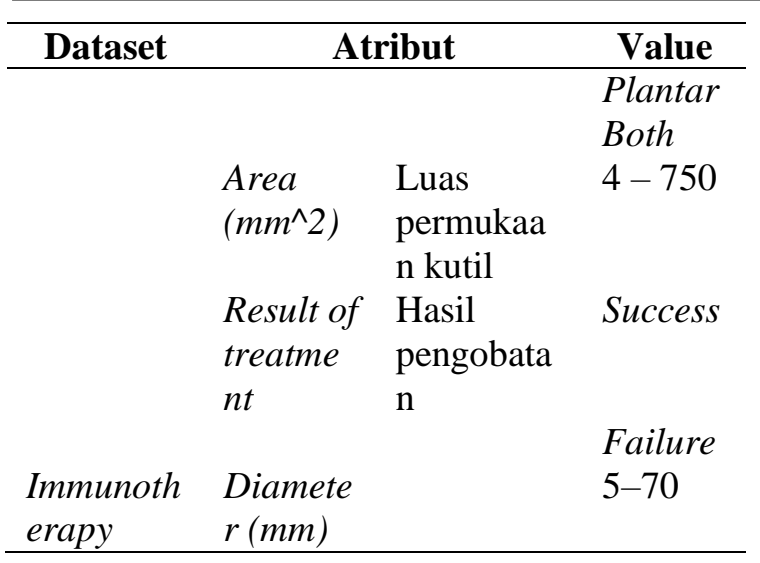

b. Persiapan dan Visualisasi Data

Data yang dikumpulkan harus dibersihkan untuk menghilangkan kesalahan, duplikat dan nilai-nilai yang hilang. Data harus diacak untuk menghilangkan efeknya dari urutan tertentu. Tugas visualisasi harus dilakukan untuk mendeteksi hubungan antar atribut atau untuk melakukan analisis eksplorasi. Data yang diperoleh pada tahap pengumpulan data tidak terdapat kesalahan dan duplikat. Selanjutnya, dataset dibagi dalam pelatihan dan pengujian. Pada penelitian ini dataset dibagi menjadi dua, yaitu $75 \%$ (67 data) untuk data latih dan 25\% (23 data) untuk data uji.

\section{c. Pemilihan Model}

Memilih algoritma sesuai tugas yang ditentukan. Pada penelitian ini akan dibandingkan performa algoritma Naive Bayes dan Neural Net untuk data immunotherapy dan cryotherapy.

d. Pelatihan

Model dilatih berdasarkan kumpulan data pelatihan, sehingga dapat membuat prediksi.

e. Evaluasi

Kinerja model diukur berdasarkan kumpulan data uji.

\section{HASIL DAN PEMBAHASAN}

Model dilatih dan diuji dengan rasio 75:25. Fungsinya train_test_split didefinisikan sebagai train_test_split $(\mathrm{X}, \mathrm{Y}$, test_size $=0.25$, random_keadaan $=0$ ). Di sini test_size adalah 0,25 , yang berarti $75 \%$ data digunakan untuk pelatihan dan $25 \%$ untuk pengujian. Untuk keseragaman dalam kinerja model nilai random_state diatur ke 0 .

a. $\quad$ Proses Testing dengan Naive Bayes Model dilatih dan diuji dengan

Algoritma Naive Bayes untuk data immunotherapy dan cryotherapy. Gambar gambar di bawah ini merupakan perbandingan visualisasi grafik hasil testing setiap atribut untuk data immunotherapy dan cryotherapy.

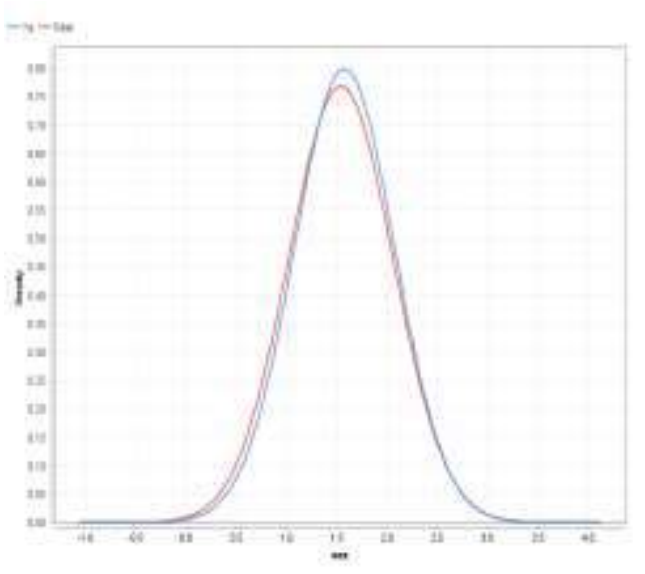

(a).

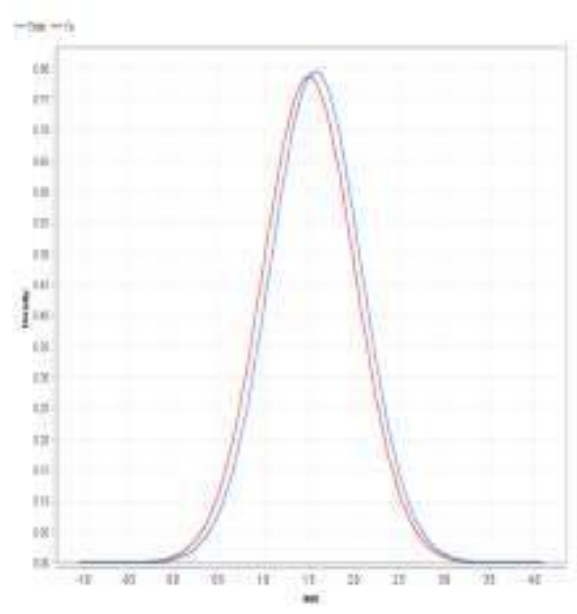

(b)

Gambar 2.(a). Immunotherapy atribut Sex (b). Cryotherapy atribut Sex

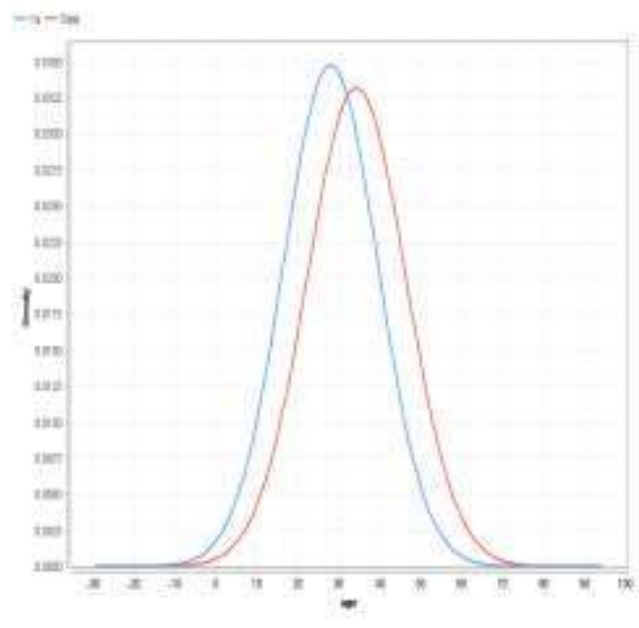

3.(a) 


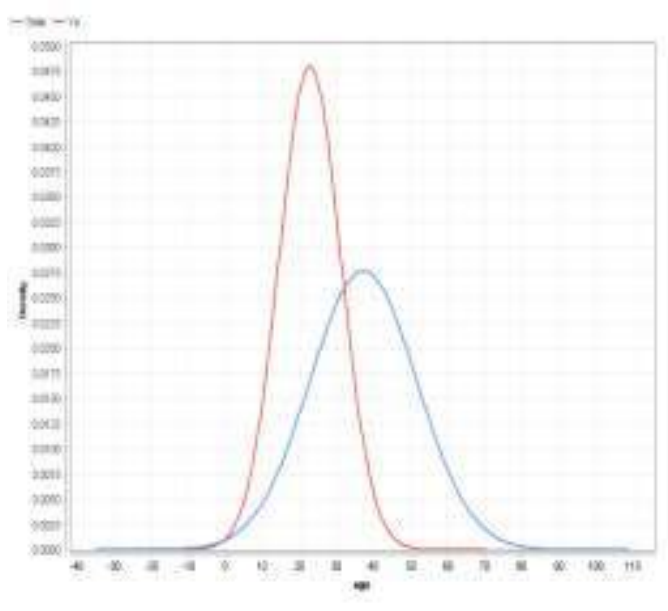

3.(b)

Gambar 3a). Immunotherapy atribut Age

(b). Cryotherapy atribut Age

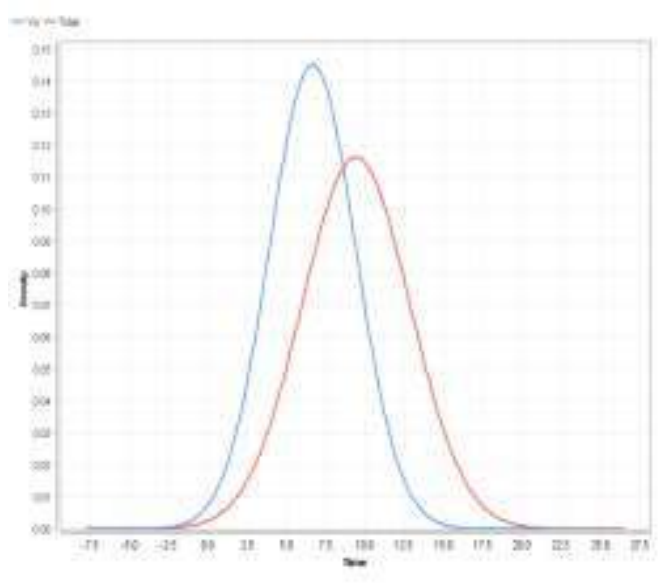

4.(a)

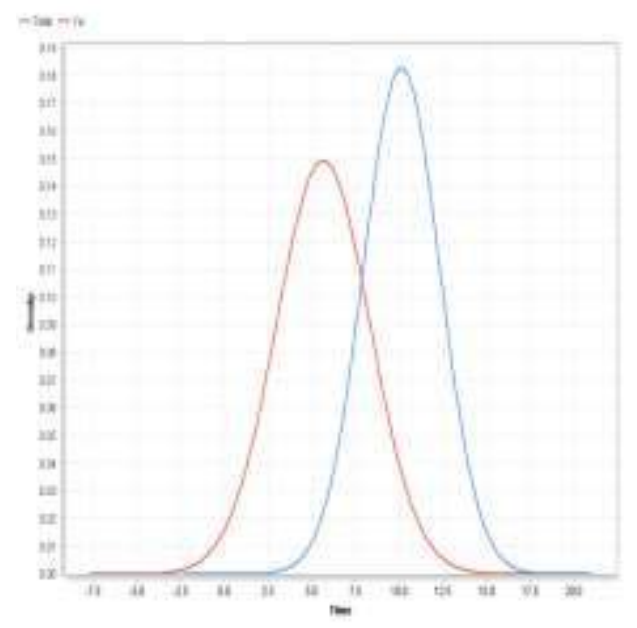

4.(b)

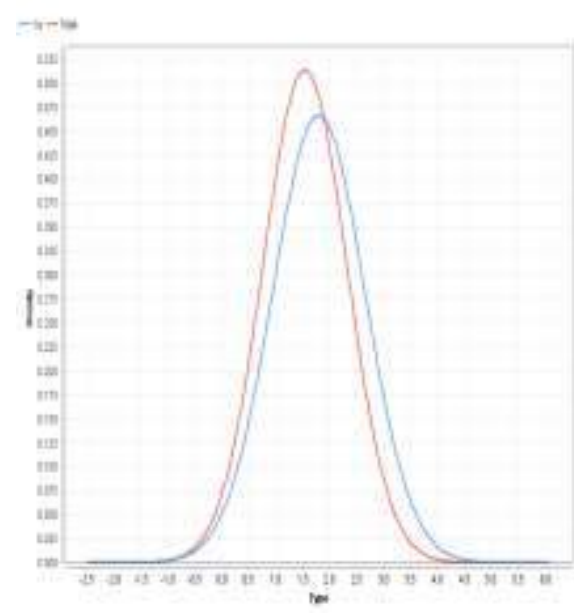

$5(a)$

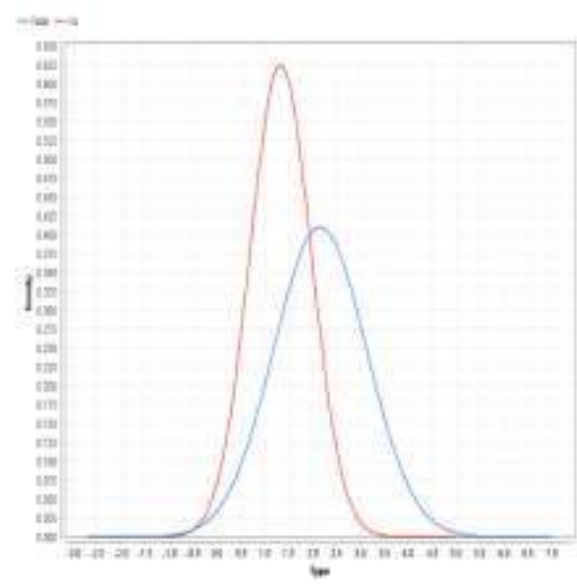

5.(b)

Gambar 5.(a). Immunotherapy atribut Time (b). Cryotherapy atribut Time

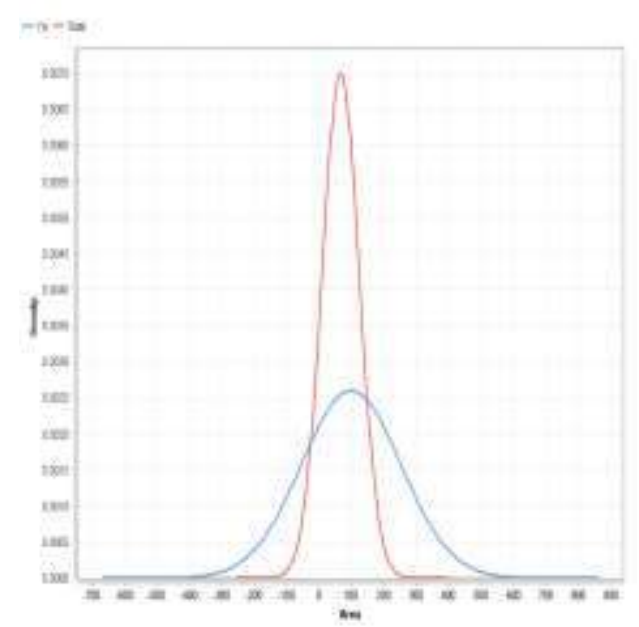

Gambar 4.(a). Immunotherapy atribut Time (b). Cryotherapy atribut Time 6.(a) 


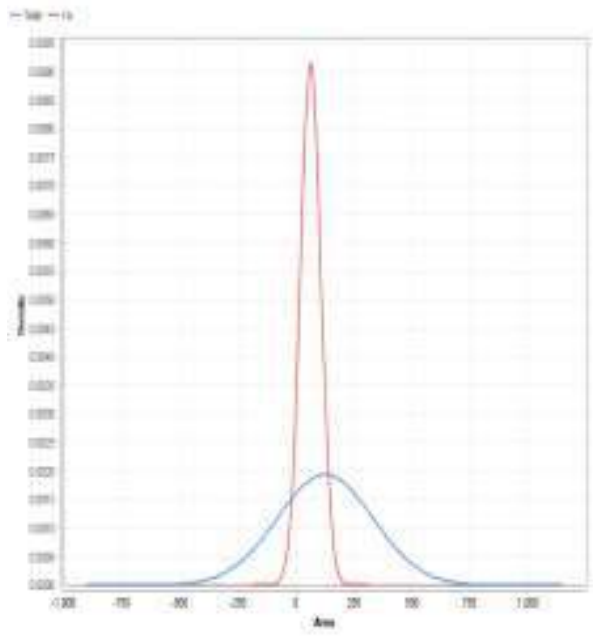

6.(b)

Gambar 6.(a). Immunotherapy atribut Area (b). Cryotherapy atribut Area

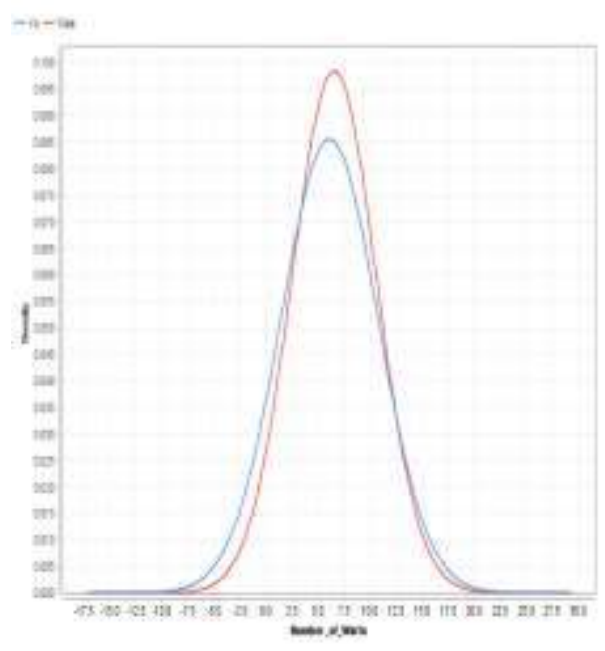

6.(a)

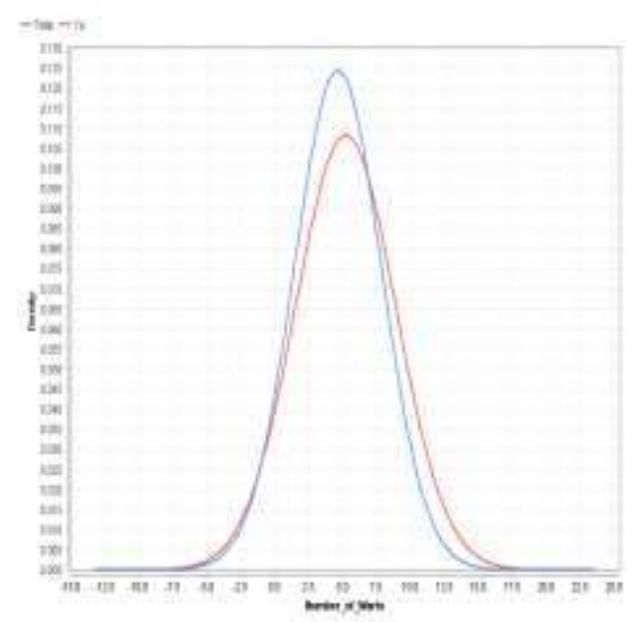

6.(b)
Gambar 6.(a). Immunotherapy atribut Number of Warts

(b). Cryotherapy atribut Number of Warts

b. Proses Testing dengan Neural Net Model dilatih dan diuji dengan Algoritma Neural Net untuk data immunotherapy dan cryotherapy. Gambar gambar di bawah ini merupakan perbandingan model hasil pengujian Neural Net untuk data immunotherapy dan cryotherapy.

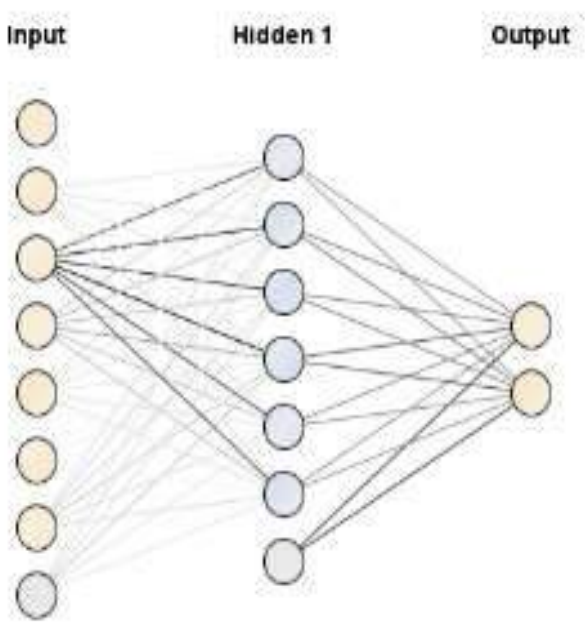

Gambar 7. Model hasil pengujian Neural Net untuk data immunotherapy

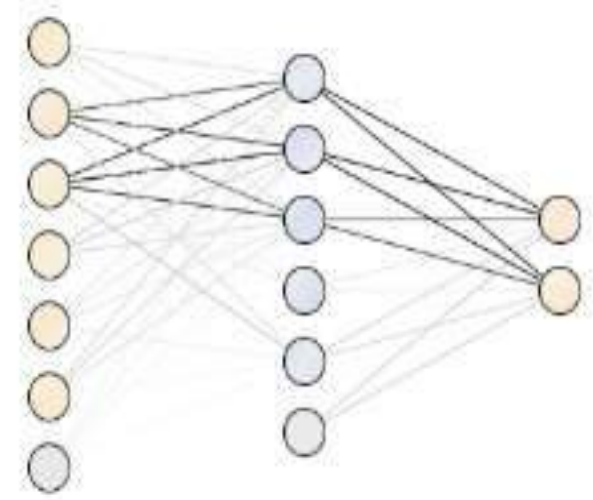

Gambar 8. Model hasil pengujian Neural Net untuk data cryotherapy 
c. Kinerja Model

Penelitian ini bertujuan untuk menguji akurasi dari analisa tingkat keberhasilan cryotherapy dan immunotherapy menggunakan algoritma naive bayesian dan neural network, data yang dianalisa adalah data cryotherapy dan immunotherapy yang diperoleh dari UCI Repository. Dengan bantuan rapid miner ternyata dapat diketahui algoritma neural network mempunyai akurasi yang tinggi.

Tabel 2. Hasil Kinerja Model

\begin{tabular}{lcc}
\hline & NN & NB \\
\hline Cryotherapy & $91.3 \%$ & $86.96 \%$ \\
Immunotherapy & $82.61 \%$ & $69.57 \%$ \\
\hline
\end{tabular}

\section{KESIMPULAN}

Berdasarkan eksperimen yang telah dilakukan dalam penelitian ini, dataset cryotherapy dan immunotherapy di dalamnya terdapat atribut-atribut yang menunjukkan kondisi proses dan class sebagai kondisi berhasil atau tidak, diuji menggunakan algoritma klasifikasi machine learning naive bayes dan neural network. Hasil efektifitas menggunakan neural network yang menghasilkan accuracy cukup tinggi 91.3\% untuk data cryotherapy dan $82.61 \%$ untuk data immunotherapy yang artinya termasuk dalam kategori klasifikasi baik sehingga dataset ini dapat menjadi salah satu tolak ukur dalam memprediksi keberhasilan dalam melakukan metode pengobatan cryotherapy dan immunotherapy.

\section{SARAN}

Saran ditampilkan dalam bentuk naratif tanpa penomoran yang merupakan usulan/ide yang bertujuan agar penelitian menjadi lebih baik lagi/adanya peningkatan terhadap hasil.

\section{DAFTAR PUSTAKA}

[1] Gerlero P, Hernández-Martín Á. "Treatment of warts inchildren": an update. Actas Dermosifiliogr 2016;107:551-558.

[2] Leung L. "Recalcitrant nongenital warts". Aust Fam Physician. 2011;40:40-42.
[3] Bavinck JN, Eekhof JA, Bruggink SC. "Treatments for common and plantar warts". BMJ 2011;342:d3119.

[4] Buttaravoli P, "Leffler SM. Warts: (common wart, plantar wart)". In: Buttaravoli P, Leffler SM, editors. Minor emergencies. 3rd ed. Philadelphia: Elsevier Saunders, 2012:752-755.

[5] Esterowitz D, Greer KE, Cooper PH, Edlich RF. "Plantar warts in the athlete". Am J Emerg Med 1995;13:441 443.

[6] El-Khalawany M, Shaaban D, Aboeldahab S. "Immunotherapy of viral warts: myth and reality". Egypt J Dermatol Venerol 2015;35:1-13.

[7] Hogendoorn GK, Bruggink SC, Hermans KE, Kouwenhoven STP, Quint KD, Wolterbeek R, et al. "Developing and validating the cutaneous WARTS (CWARTS) diagnostic tool: a novel clinical assessment and classification system for cutaneous warts". $\mathrm{Br} \mathrm{J}$ Dermatol 2018;178:527-534.

[8] Micali G, Lacarrubba F. "Standardized classification tools in dermatology: time to focus on cutaneous warts". Br J Dermatol 2018;178:330

[9] Yashik Singh. "The Application of Machine Learning in Predicting Outcome of Cryotherapy and Immunotherapy for Wart Removal". Ann Dermatol Vol. 33, No. 4, 2021

[10] Anuradha, C \& T. Velmurugan. "A Comparative Analysis on the Evaluation of Classification Algorithms in the Prediction of Students Performance". Vol.8. Bharathiar University, India. 2015.

[11] Riski Annissa. "Analisis Komparasi Algoritma Klasifikasi Data Mining Untuk Prediksi Penderita Penyakit Jantung". 
Jurnal Teknik Informatika Kaputama

(JTIK). Vol.3. No. 1. Jan 2019 